\title{
Materia Fina \& Arenas de Lesbos
}

\section{Silvio Ambrogi o la imagen como paraíso}

Recibido: 10.06.2015/ Aprobado: 30.06.2015

Por Erwin Silva ${ }^{2}$

$\mathrm{E}$ n los poemas de Silvio Ambrogi más allá del ritmo que quisiera imponer o de los neologismos que él deseara crear, o bien de la expresión americana de su español, la imagen aparece en un inevitable torbellino que decide el destino de su poesía.

En la poesía de Ambrogi, el deseo genera imagen y la nostalgia el paisaje. Es decir, esto es su arte poética que "todo se disuelve en imagen que canta el íntimo deseo", como el mismo poeta dice. Hay de poeta y de pintor a la vez, lo he dicho ya, pero vale reiterarlo porque es así; las palabras son a veces los óleos en la paleta o el pincel es la manera de decir las cosas; Ambrogi se demora y se deleita en las descripciones de la naturaleza, incluso las referencias y poetizaciones de los pintores como Millet o Van Gogh no son extrañas y son metapictóricas. La naturaleza que va siendo cada vez más infrecuente en la poesía contemporánea, no es simple telón de fondo sino la creación o aparición proyectada por una refinada sensibilidad de lo visto en la tierra natal o en su propia imaginación. Sin embargo, nuestro autor, va a la aventura en una ruta insospechada tras la imagen que será al fin su paraíso. Silvio Ambrogi vivirá a la sombra de este paradiso de donde surgen los colores del atardecer o las figuras trazadas en arenas de Lesbos.

En estos poemas marcados por un decir tradente de la poesía nicaragüense también se ve rondar tras los quietos cristales la silueta de Don José Lezama Lima, con su sistema poético, pleno de brújulas imantadas por el trópico, el abigarrado utillaje barroco y Góngora al cuadrado.

Ambrogi, lector profundo de Lezama trasluce y luce de estos juegos del imago, pero es aún más que esto, la imagen es la figura preferida como el laúd lo fuera del trovador.

En su erotismo, espejo de lo semejante, Ambrogi recorre los cuerpos con delicia así como el otoño nos cubre con su memoria de hojas caídas o el llamado a la tibieza de lo íntimo mientras se oyen las viejas canciones. Igual el amor se pliega y se repliega bajo los disfraces y las imágenes posibles. Soledades y ausencias rondan y recuerdos de antiquísimas ciudades se diluyen en la nada, pero el amor prevalece en estos poemas como una materia fina, astral, inconsútil. En Arenas de Lesbos, se asume la voz de Safo, quien se autodeveliza en el eros que no alcanza, por esto recordemos de Ella aquellas líneas en unos fragmentos de papiro "Es medianoche y la luna y las pléyades se han puesto y yo sigo durmiendo sola": Voz e impostación que Ambrogi logra por medio de la mnemosine que le viene de los mitos, por cierto los mitos griegos en los que Ambrogi se ha adentrado con sabiduría y esplendor.

Silvio Ambrogi es habitado por las Gracias, en movimiento y trino, pero lo es más por la belleza del verbo con el que vuelve a nombrar las cosas o a crear un trasmundo con la sola virtud de la palabra y cuyos fulgores vemos en la unidad de esta poesía.

1 Primera edición. Editorial Industria Serigráfica Gómez Vega, Cía. Ltda- Managua 2014.

2 Poeta y profesor. E- mail:matesislogos@gmail.com 


\section{Literatura}

\section{Selección de poemas Materia Fina \& Arenas de Lesbos}

\section{Materia Fina}

Vi trozos de lunas caer sobre jicaral dormido plateando ronda de estrellas palpitando lejos su canción sonámbula...

vertical rocio

nube de pluma áspera ilusión de mar nocturno...

bija que el viento eteriza su ondulada procesión abismal de caidas

- Una pequeñez de luz que surge sigilosallave de lo oscuro modulado - Ábranse las puertas del jardin ocultoarde la carne de silencios... duro-son del cascado bueso del sueño... pétalos roidos por la brisa rosa desbecha de inocencias afelpado susurro del fresco césped macbucado por ciego paso de visitante berido y la navaja que gotea su carmin encendido cae en lágrimas la sexoledad de grito mudo serena sombra del caballo donde el cucbillo pisa traición liviana de lluvia.

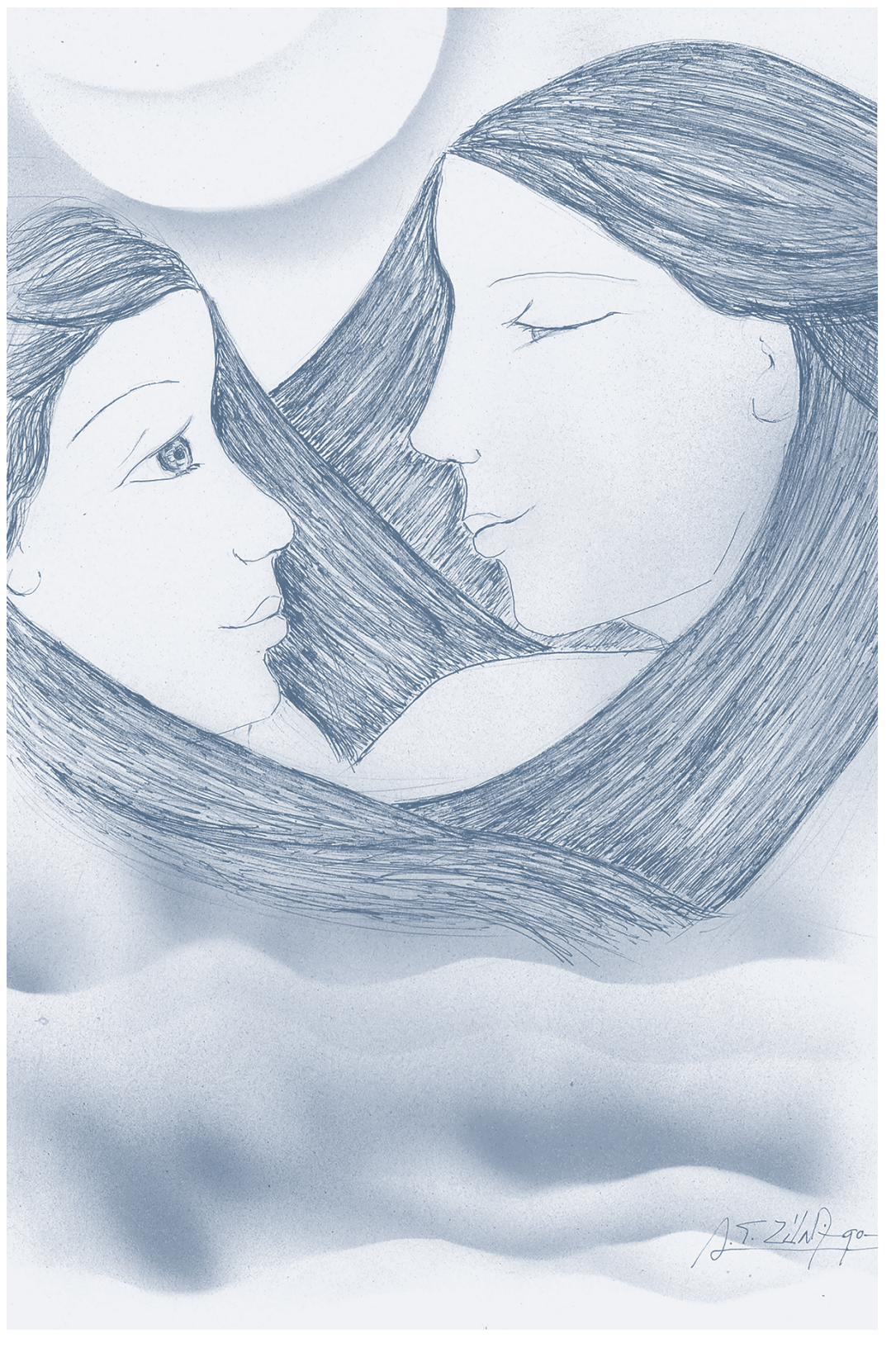

Autor: Silvia Zúniga 


\section{Loiteratura}

\section{Sombra lacustre}

Al poeta Santiago Molina $R$

Recogi migajas de luna tierna

esa boz diminuta e intensa como bueso meálico

palpitando en cálidas noches del trópico sobre matorrales de espesa oscuridad

adelantindose la débil mano de las sombras

titilan los astros en cielares de Amerrisque

bajando sus geometrias indescifrables

donde la serpiente empluma

cuando deja su piel de lustre escamoso

lucia pasta de muda tornasol.

Hay un despojo enmarañado y fitido

en las crisálidas de las metamorfosis el acurrucado canto de pocoyos

débil Sacuanjoche de liquidos contornos

el sigiloso rio donde lloran las piedras

es vertiente de interrogaciones

y corren a morir en el cuerpo verdoso de los lagos

la profundidad vegetal se me adbiere

como el roció impregna las bojas del amanecer

desnudez desamparada de la orquidea

Solo una ribera de oscurecidas arenas

duerme el paso certero del venado.

Forastero lucero que irradia centella

en desazón de fauces nocturnas

tragando desgano del cieroo muerto.

Una mudez lunar detiene el instante

del cuerpo trasnochado y ambiguo

el mentido caracol es la cárcel del sueño...

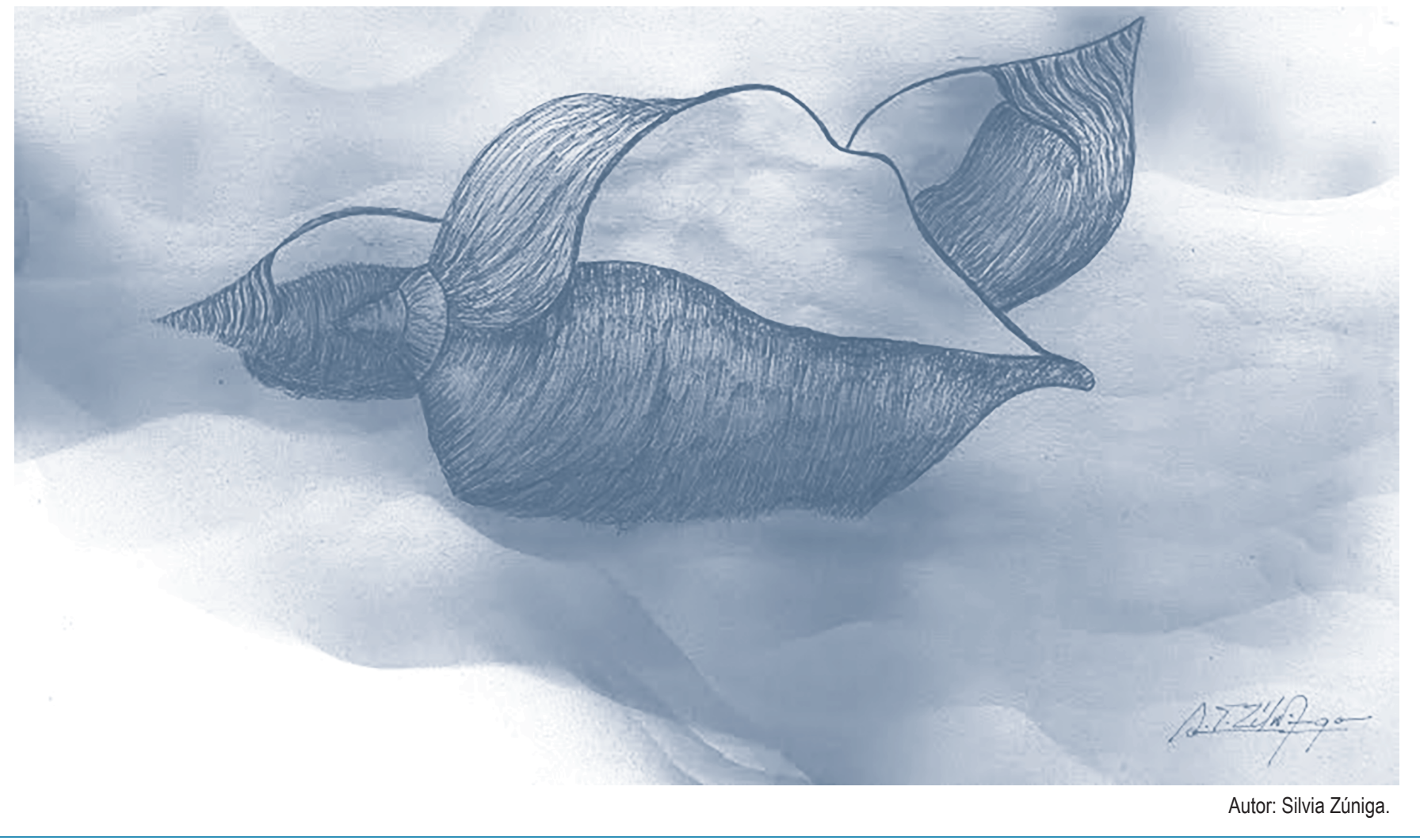




\section{Literatura}

\section{Tocturnal}

Al escritor Julio Pino Mliyar

Hay una región en la memoria anegada de olvidos

cuando transitan los silencios intermedios. entre el alma y la razón se acomoda una distancia oblicua ...

la espera es una columna de granito donde seres anónimos rodean la ausencia del numero. La cifra del sueño navega el imposible rostro desconocido dilema que fractura al no Ser. Una grieta de instantes nace en el ojo vigilante del Todo. Heladas sombras de vacios penetrada por ondulación perfecta de luz. Abanicos de posibles tristezas deshojan la invasión amarilla del otoño. Tensa el viento su invisible violin detenido en el pinar zigzaguea sombrea sobre luminarias eléctricas que riela temblando en el agua discursioa del umbroso canal.

Es un espejo oscuro de seres imposibles que se alejan en el adiós.

Tocturno vigilante que en la rama seca divisa la buella infinita del ayer. La dilatada pupila deambula en senderos marcbitos de sexoledad cae la lluvia sobre pardos tejados deshabitadas casas donde llora un Ciprés. Un lamento gatuno se desliza estitíndose más allá de la nocbe. La cerrada puerta duerme su mutilado insomnio de curoada soledad.

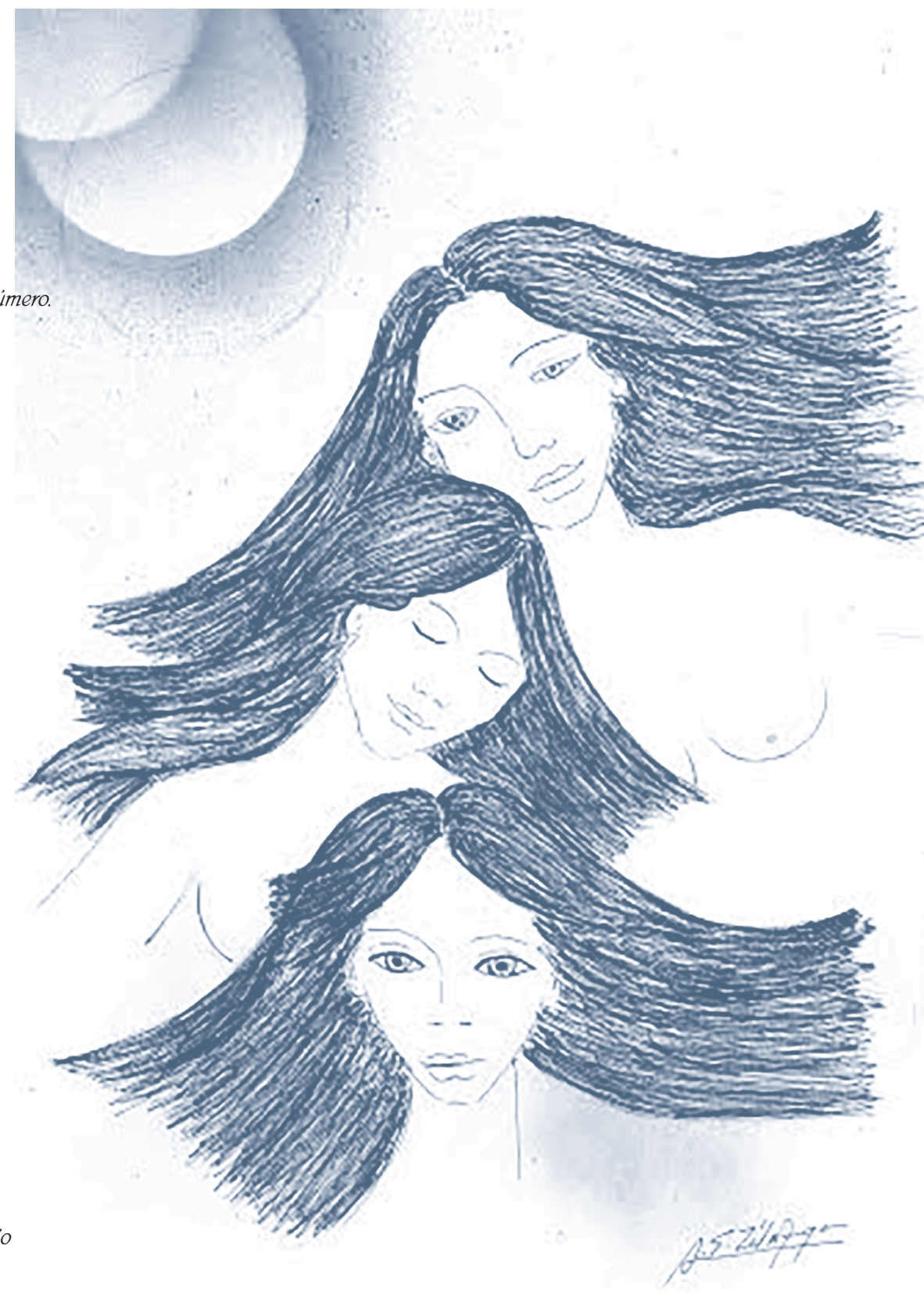

Autor: Silvia Zúniga. 